\title{
NF-kB mediated down-regulation of collagen synthesis upon HEMA (2-hydroxyethyl methacrylate) treatment of primary human gingival fibroblast/Streptococcus mutans co-cultured cells
}

\author{
R. Grande • S. Pacella • M. Di Giulio • M. Rapino • \\ V. Di Valerio $\cdot$ L. Cellini $\cdot$ A. Cataldi
}

Received: 4 November 2013 / Accepted: 15 August 2014 / Published online: 9 September 2014

(C) The Author(s) 2014. This article is published with open access at Springerlink.com

\begin{abstract}
Purpose In vitro studies have evidenced the cytotoxic effect of HEMA (2-hydroxyethyl methacrylate), the most common component of dental resin-based restorative material, which is released within the oral cavity, on eukaryotic cells such as gingival fibroblast and epithelial cells. However, since the presence of microorganisms within the oral cavity cannot be excluded and little is known about the interactions occurring between eukaryotic cells and the human oral microbiota, our attention has been addressed to investigate the effect of $3 \mathrm{mM}$ HEMA on the molecular mechanisms driving the response of human gingival fibroblasts (HGFs) co-cultured with Streptococcus mutans.

Methodology HGF/S. mutans co-culture has been set up in our lab, and upon HEMA treatment, S.mutans and HGF cells' viability and adhesion along with type I collagen gene and pro-collagen I, Bax, Bcl2, nuclear factor $\mathrm{kB}(\mathrm{NF}-\mathrm{kB}), \mathrm{IkB} \alpha$, $\operatorname{pIkB} \alpha$ protein expression by PCR, Western blotting and ELISA assays have been investigated.

Results HEMA treatment determines a significant decrease of type I collagen protein production, even in the presence of $S$. mutans, in parallel to a decrease of cell viability and adhesion, which seem to be regulated by NF-kB activation. In fact, when SN50, NF-kB-specific pharmacological inhibitor, is added to the culture, cell proliferation along with collagen synthesis is restored.
\end{abstract}

\footnotetext{
R. Grande $\cdot$ M. Di Giulio $\cdot$ L. Cellini $\cdot$ A. Cataldi $(\bowtie)$

Dipartimento di Farmacia, Università G. d'Annunzio,

Chieti-Pescara, 66100 Chieti, Italy

e-mail: cataldi@unich.it

S. Pacella $\cdot$ V. Di Valerio

Dipartimento di Medicina e Scienze dell'Invecchiamento, Università

G. d'Annunzio, Chieti-Pescara, 66100, Chieti, Italy

M. Rapino

Istituto di Genetica Molecolare del CNR, Unità di Chieti, Chieti, Italy
}

Conclusion The modulation exerted by $S$. mutans on the cytotoxic effect of HEMA suggests that within the oral cavity, the eukaryotic/prokaryotic cell interactions, maintaining the balance of the environment, allow HEMA to perform its adhesive and bonding function and that the use of a coculture system, which simulates the oral cavity organization, improves the knowledge concerning the biocompatibility of this dental material.

Keywords NF-kB · Type I collagen · HEMA · HGF/

Streptococcus mutans co-cultured cells

\section{Introduction}

Among the components of dental resin materials, which are released into aqueous or organic solvents, 2hydroxyethyl methacrylate (HEMA) is included $[1,2]$. This wetting monomer agent, which facilitates penetration of the hydrophilic component, like BisGMA and UDMA into hydrophilic environments like dentin [3], in vivo can be released into the oral cavity, as observed in dental practice $[4,5]$, or into the pulp space [6] inducing toxic effect on eukaryotic cells, such as gingival fibroblast and epithelial cells [7-15].

Although the in vitro response to HEMA evidences immunogenic, teratogenic, genotoxic, inflammatory, oxidative cell damage and apoptosis in the eukaryotic cells of the oral cavity $[4,16]$, it should not be forgotten that also numerous bacterial strains with commensal and pathogen significance are represented in this environment [17-19] and such material might affect interactions between eukaryotic and prokaryotic cells.

Oral streptococci encompass friends and foe bacteria. Imbalance in the indigenous microbial environment generates oral diseases, and under proper conditions, 
commensal streptococci can switch to opportunistic pathogens that initiate disease and damage to the host. Streptococcus mutans is one of the strains naturally present in the human oral microbiota and is the most important bacterium related to the formation of the dental caries, thanks to its capability to produce an acidic environment and to form sticky biofilm [20-23]. However, some authors have not detected this species in children patients with caries and when found, it was part of a complex microbial community $[24,25]$. Dental caries process is associated to the development of dental plaque or biofilm in which the bacterial community, embedded in the extracellular polysaccharide (EPS) matrix adhered to the tooth surface, causes the demineralization of dental hard tissue through the production of acids from dietary sugars. The presence of a cariogenic species, like S. mutans, and/or biomaterials, like HEMA, alone and in combination with each other, might induce a cellular response of the oral tissues, in terms of gene and protein expression [26, 27].

Nuclear factor $\mathrm{kB}(\mathrm{NF}-\mathrm{kB})$ is a dimeric transcriptional factor which activates a great variety of genes involved in stress response, immune cell activation, cancer occurrence, cell growth, inflammation, programmed cell death and survival [28-36]. NF-kB activation is regulated by a multi-subunit IkB kinase (IKK-B) complex which phosphorylates $\mathrm{IkB} \alpha$ marking it for degradation by ubiquitin pathway, so that NF-kB dimer can translocate to the nucleus, bind DNA and activate transcription genes [37]. Even though NF-kB is also involved in the protection against apoptosis induced by HEMA in mouse embryonic fibroblasts [38] and in dental pulp stromal cells and oral keratinocytes [39, 40], no evidence concerning the role played by NF-kB intracellular signalling pathway in the response to HEMA in the presence of bacterial strains is reported.

Thus, since in our lab a eukaryotic/prokaryotic coculture model has been set up [41, 42], the effect of $3 \mathrm{mM}$ HEMA on the molecular mechanisms driving the response of human gingival fibroblast (HGF) co-cultured with $S$. mutans has been evaluated. We have chosen to use 3 mM HEMA according to previous studies by Falconi et al. [43], in which $3 \mathrm{mM}$ HEMA has been demonstrated to be responsible for a reduction of cell viability lower than $50 \%$, and by Kurata [16], which shows a drastic anti-proliferative effect of $1 \mathrm{mM}$ HEMA followed by a further increase at 3 and $5 \mathrm{mM}$ in fibroblasts derived from human pulp.

In addition, being fibroblast cells producer of collagen type I, which allows cell-cell or cell-substrate adhesion [28] and nuclear transcription factor NF-kB a regulator of collagen biosynthesis $[29,30]$, here we report the response disclosed by HGF cells to HEMA in terms of adhesion and proliferation in the presence of $S$. mutans.

\section{Materials and methods}

Bacterial strain and growth condition

The reference strain S. mutans ATCC 25175 has been cultured in Trypticase soy broth (Oxoid, Milan, Italy) at $37^{\circ} \mathrm{C}$ for 18 $24 \mathrm{~h}$ under anaerobic atmosphere. The overnight culture has been diluted 1:10 $(v / v)$ in Dulbecco's modified Eagle's medium (DMEM, Euroclone, Milan, Italy) antibiotic and serumfree plus $1 \%(w / v)$ sucrose and refreshed for $2 \mathrm{~h}$ at $37^{\circ} \mathrm{C}$ in an orbital shaker (Julabo SW-20 C, Milan, Italy) at $160 \mathrm{rpm}$ in aerobic condition. The broth culture has been adjusted to 0.5 McFarland, corresponding to approximately $1.5 \times 10^{8} \mathrm{CFU} / \mathrm{ml}$ and used for co-culture set-up.

\section{Culture of human gingival fibroblasts}

HGFs have been obtained from fragments of healthy marginal gingival tissue taken from the retromolar area during surgical extraction of impacted third molars. Signed informed consent has been obtained from the donors. Tissue fragments have been immediately placed in Dulbecco's modified Eagle's medium (DMEM)/F12 for at least $1 \mathrm{~h}$, rinsed three times in phosphate-buffered saline solution (PBS), minced into small tissue pieces and cultured in DMEM/F12, $10 \%$ foetal bovine serum (FBS), $1 \%$ penicillin and streptomycin and $1 \%$ fungizone. Cells have been maintained at $37{ }^{\circ} \mathrm{C}$ in a humidified atmosphere of $5 \%(v / v) \mathrm{CO}_{2}$ and after 4-8 passages have been seeded into 96-well and 6-well culture plates (Nunc, EuroCloneSpA, Life-Sciences-Division, Milan, Italy) with DMEM containing $10 \% \mathrm{FBS}$, penicillin and streptomycin. The NF-kB/IkB pharmacological inhibitor SN50 $(50 \mu \mathrm{M})$ (Enzo Life Sciences, Lausen, CH4415 Switzerland) [44] has been added to the cells 45 min before S.mutans and HEMA.

HEMA treatment and co-colture set-up

2-Hydroxyethyl-methacrylate (HEMA) (Sigma-Aldrich, Milan, Italy) stock solution $1 \mathrm{M}$ in ethanol has been filtered through $0.2-\mu \mathrm{m}$ pore size filters and diluted in DMEM to obtain a medium containing $3 \mathrm{mM}$ HEMA according to Falconi et al. [43]. The ethanol concentration in the medium used for the experiments was lower than $0.3 \%$. The co-culture assays, have been performed in $25-\mathrm{cm}^{2}$ flasks for the adhesion assay and 75 and $150 \mathrm{~cm}^{2}$ for multiplex reverse transcriptionPCR (MRT-PCR) and protein extraction, respectively. The HGFs have been seeded in culture plates in DMEM containing $10 \%$ FBS, $1 \%$ penicillin and streptomycin in a humidified atmosphere of $5 \%(v / v) \mathrm{CO}_{2}$ at $37^{\circ} \mathrm{C}$. When cells have reached confluence, the medium has been removed and cell washed with PBS. The bacterial cultures, standardized in DMEM $1 \%$ sucrose, have then been added to HGF confluent cells together with DMEM containing $3 \mathrm{mM}$ 
HEMA. Just the DMEM has been added to the control cultures. Moreover, S. mutans ATCC 25175 and HGFs have been assayed alone in DMEM $1 \%$ sucrose with and without HEMA. The flasks have been incubated for $24 \mathrm{~h}$ in humidified atmosphere of $5 \%(v / v) \mathrm{CO}_{2}$ at $37^{\circ} \mathrm{C}$. The choice of a single incubation time point is associated to a cell viability reduction of $S$. mutans evaluated by live/dead staining and subsequent microscopic observation after $24 \mathrm{~h}$ of incubation.

In conclusion, for the evaluation of the effect of HEMA and S. mutans ATCC25175 alone and in combination with each other on HGF cells, trypan blue dye exclusion test has been performed in the following experimental conditions:

\section{HGF (control) \\ HGF plus HEMA \\ HGF plus $S$. mutans ATCC 25175 \\ HGF plus HEMA plus $S$. mutans ATCC 25175}

For each assay, the experimental design has been carried out at least for two independent experiments and each experiment performed in triplicate.

\section{LDH cytotoxicity assay}

HGFs have been seeded at 200,000 cells/well on 24-well plates. After $24 \mathrm{~h}$, culture medium has been replaced with $1 \mathrm{ml}$ of DMEM $1 \%$ sucrose containing standardized bacterial cultures (final volume $1 \mathrm{ml}$ ). After $30 \mathrm{~min}$ at $37^{\circ} \mathrm{C}$, medium has been harvested and lactate dehydrogenase-based assay (LDH assay, TOX-7, Sigma-Aldrich, St. Louis, MO) has been performed on culture media according to manufacturer's instructions. As positive control, cells have been lysed with Triton $1 \%$. Each test has been performed in quadruplicate.

Assessment of cytotoxicity has been calculated according to the formula:

$\% \mathrm{LDH}$ released $=[(\mathrm{A}-\mathrm{B}) /(\mathrm{C}-\mathrm{B})] \times 100$,

with $\mathrm{A}=\mathrm{LDH}$ activity of sample, $\mathrm{B}=\mathrm{LDH}$ activity of untreated cells and $\mathrm{C}=\mathrm{LDH}$ activity of the positive control.

\section{S. mutans cell viability evaluation and adhesion assay}

The effect of $3 \mathrm{mM}$ HEMA on streptococcal adhesion on HGFs has been evaluated by colony forming unit (CFU) counts. S.mutans, grown as mentioned before, has been cocoltured with HGFs with and without $3 \mathrm{mM} \mathrm{HEMA}$ in $25-\mathrm{cm}^{2}$ cell culture flasks. After $24 \mathrm{~h}$ of incubation, the planktonic bacteria have been removed while sessile cells, adhered to HGFs, have been rinsed with PBS and removed by using a cell scraper plus $1 \mathrm{~mL}$ sterile PBS. The obtained sample has been homogenized at 10,500 rpm for $30 \mathrm{~s}$, at 25,000 rpm for
$40 \mathrm{~s}$ and $30,000 \mathrm{rpm}$ for $40 \mathrm{~s}$, by using a homogenizer $\left(I K A^{\circledR}\right.$ _ T10 basic Ultra, Staufen, Germany) for separating bacteria aggregates. The number of bacteria has been determined by dilution plating on Trypticase soy agar (Oxoid, Milan, Italy). The plates have been incubated for $24 \mathrm{~h}$ in anaerobic atmosphere and in aerobic atmosphere for another $24 \mathrm{~h}$ at $37^{\circ} \mathrm{C}$. Each assay has been performed for three independent experiments in duplicate.

\section{RT-PCR assay}

For the evaluation of gene expression and cell viability, HGFs have been rinsed with PBS, trypsinized and processed for trypan blue dye exclusion test, which selectively identifies dead fibroblasts in blue, and counted in a Burker chamber after $24 \mathrm{~h}$ of incubation.

With regard to RNA isolation, total RNA has been extracted from HGF cells by using QIAzolLysis Reagent [45] and DNase I digestion has been performed according to the manufacturer's instructions (Sigma-Aldrich, Milan, Italy). Total RNA $(2 \mu \mathrm{g})$ has been electrophoresed on a $1 \%$ formaldehyde agarose gel, to evaluate RNA integrity. For the evaluation of type I collagen gene expression, a multiplex reverse transcription-PCR (MRT-PCR) with the housekeeping gene glyceraldehyde 3-phosphate dehydrogenase (GAPDH) has been carried out. The oligonucleotide primers used are as follows: ha (1)-coll. 1-f (5'-CTGACCTTCCTGCGCCTGAT GTCC-3'); ha(1)-coll 1-r (5'-GTCTGGGGCACCAACGTC CAAGGG-3') for collagen-1(36); and hGAPDH-f (5'CAACTACATGGTTTACATGTTC-3') and hGAPDH-r (5'GCCAGTGGACTCCACGAC-3') for the housekeeping gene GAPDH [46]. MRT-PCR has been performed by using the One-Step RT-PCR Kit (Qiagen, Milan, Italy) in a final reaction volume of $25 \mu \mathrm{l}$ containing $160 \mathrm{ng}$ of total RNA, 1× Qiagen buffer, $500 \mathrm{mM}$ of each dNTP, $0.6 \mathrm{mM}$ of each primer and $5 \mathrm{U}$ of One-Step RT enzyme. RT-PCR Master Mix has been performed in a 2700 thermocycler (Applied Biosystems, Foster City, CA, USA) for $30 \mathrm{~min}$ at $50{ }^{\circ} \mathrm{C}$ and $15 \mathrm{~min}$ at $95{ }^{\circ} \mathrm{C}$ for $\mathrm{RT}$ and initial PCR activation, respectively. The amplification of Collagen I/GAPDH gene consisted of $15 \mathrm{~min}$ at $95{ }^{\circ} \mathrm{C}$ and then 35 cycles of $30 \mathrm{~s}$ at $94^{\circ} \mathrm{C}, 1 \mathrm{~min}$ at $63{ }^{\circ} \mathrm{C}$, $1 \mathrm{~min}$ at $72{ }^{\circ} \mathrm{C}$, with a final $10 \mathrm{~min}$ extension at $72{ }^{\circ} \mathrm{C}$. To assess the specificity of the primers used in the experiment, a sample containing just $S$. mutans ATCC 25175 RNA has been processed as negative control: no amplification products have been detected.

PCR products $(6 \mu \mathrm{l})$ have been analysed by electrophoresis in a $2 \%(w / v)$ agarose gel at $100 \mathrm{~V}$ for $45 \mathrm{~min}$. Gels have been stained with ethidium bromide and photographed. The expected sizes of the amplification products have been approximately $300 \mathrm{bp}$ for Collagen-I and $181 \mathrm{bp}$ for GAPDH, respectively.

The relative level of expression for each gene has been calculated as the ratio between the signal obtained in the area 
of the target band and the signal of the GAPDH, by scanning densitometry by using the GELDOC XRS system by the QuantiOne 1-D analysis software (BIORAD, Richmond, CA, USA). Two independent experiments, performed in duplicate, have been carried out.

\section{Western blotting analysis}

Total cell lysates $(60 \mu \mathrm{g})$ have been electrophoresed on a $10 \%$ sodium dodecyl sulphate (SDS)-polyacrylamide gel and transferred to nitrocellulose membrane. Nitrocellulose membranes, blocked in $5 \% \mathrm{BSA}, 10 \mathrm{mmol} / \mathrm{L}$ Tris- $\mathrm{HCl} \mathrm{pH} \mathrm{7.5,} 100 \mathrm{mmol} /$ $\mathrm{L} \mathrm{NaCl}$ and $0.1 \%$ Tween-20, have been probed with mouse anti $\beta$-actin and anti $\beta$-tubulin antibodies (Sigma, USA), goat pro-collagen I, mouse anti-BAX, mouse anti BCL2 antibodies (Santa Cruz, Santa Cruz Biotechnology, CA, USA), polyclonal anti NF-kB, IkB $\alpha$ and $p-I k B \alpha$ antibodies (Cell Signalling Technology) and then incubated in the presence of specific enzyme-conjugated IgG horseradish peroxidase. Immunoreactive bands have been detected by ECL detection system (Amersham Intl., Buckinghamshire, UK) and analysed by densitometry. Densitometric values, expressed as integrated optical intensity (IOI), have been estimated in a CHEMIDOC XRS system by the QuantiOne 1-D analysis software (BIORAD, Richmond, CA, USA). Obtained values have been normalized basing on densitometric levels of internal $\beta$ tubulin and $\alpha$-actin.

\section{ELISA assay}

Type I collagen secretion has been evaluated on both experimental discs and polystyrene plates at $24 \mathrm{~h}$ of culture by means of ELISA assay (Human Collagen type I ELISA, COSMO BIO CO., LTD), according to manufacturer's instructions.

\section{Statistical analysis}

The significance of the differences recorded in the assay performed with and without HEMA in each experimental condition has been evaluated using Student's $t$ test. Probability levels of $<0.05$ have been considered statistically significant. Statistical analysis has been performed using the analysis of variance (ANOVA). Results have been expressed as mean \pm SD. Values of $p<0.05$ have been considered statistically significant.

\section{Results}

Light phase contrast microscopy analysis evidences that fibroblasts loose adhesion upon HEMA treatment also in the presence of $S$. mutans, while trypan blue dye exclusion test shows that cell viability is still high after $24 \mathrm{~h}$ of treatment in all the experimental conditions (Fig. 1a, b). No effect of HEMA on bacteria viability, assayed by CFU counts, is observed, while when an LDH assay, which is considered a cytotoxicity assay, has been performed, the cytotoxic effect of HEMA is reduced in the presence of $S$. mutans (Fig. 1c, d). Even though no difference is evidenced when procollagen I gene expression is evaluated in HGF by using GAPDH as housekeeping gene (Fig. 2a, b), Western blotting analysis shows a significant decrease of procollagen I protein level in HGF samples treated with HEMA alone and in the presence of S. mutans for $24 \mathrm{~h}$, while no difference is revealed between untreated cells and co-cultures without HEMA (Fig. 2c, d). Since a direct correlation has been demonstrated between collagen gene suppression and NF-kB activation, we have investigated if HEMA is able to activate this signalling pathway, which plays a key role in the regulation of stress response genes. Both NF-kB and IkB expressions have been tested revealing no differences in the different experimental conditions, while an increased $\mathrm{p}-\mathrm{IkB} \alpha / \mathrm{IkB} \alpha$ ratio is shown in HGF treated with HEMA and also in co-cultures in the presence or not of HEMA (Fig. 3). In the cells which loose adhesion apoptotic events seem to be switched on, as shown by increased level of pro-apoptotic Bax protein, as well as by decreased level of anti-apoptotic Bcl-2 protein, in those cells treated only with HEMA (Fig. 4), coming back to basal levels in the presence of S. mutans, even though when an Annexin/ PI assay, which detects early apoptosis, has been performed, no difference has been evidenced in the different experimental conditions (data not shown). Interestingly, when, to add specificity to such results, the NF-kB/lkB pharmacological inhibitor SN50 is administered to the co-cultures 45 min before S. mutans and HEMA treatment, collagen secretion, evidenced by ELISA assay, is restored (Fig. 5) as well as LDH activity and $\mathrm{p}-\mathrm{IkB} \alpha / \mathrm{IkB} \alpha$ ratio are decreased (Figs. 1 and 3). Moreover, Bax expression does not undergo modification in the presence of SN50 inhibitor (Fig. 4).

\section{Discussion}

Oral and systemic diseases are frequently related to the effects of released dental restorative materials and of adherence of microbial species to oral cavity tissues. Even though a lot of studies concerning the effects exerted by HEMA, TEGDMA and other dental biomaterials on oral tissue are published $[1,2$, 4], it is of great interest to know how the presence of pathogenic bacterial community on oral tissue may interfere with eukaryotic gene expression and protein synthesis in the response to biomaterials. As Johansson A. et al. [47] suggest, the oral disease may not be due to the presence of oral 
Fig. 1 a Light phase contrast microscopy of co-cultured human gingival fibroblasts (HGF)/ S. mutans ATCC 25175 in different experimental conditions. Arrows indicate dead cells. Magnification $\times 10$. b Trypan blue dye exclusion test of primary cultures of HGF exposed for $24 \mathrm{~h}$ to $3 \mathrm{mM}$ HEMA co-cultured or not in the presence of $S$. mutans ATCC 25175. Data are the mean of three separate experiments $( \pm \mathrm{SD})$. c Effect of 3 mM HEMA on the viable growth of $S$. mutans ATCC 25175 in co-culture with human gingival fibroblast after $24 \mathrm{~h}$ of incubation. Viable growth of S. mutans ATCC 25175 adherent on HGF with and without HEMA. Data are the mean of three separate experiments $( \pm \mathrm{SD})$. d LDH release in HGF in different experimental conditions. Graph represents the mean percentage $\pm \mathrm{SD}$ of three experiments. $C$ HGF (control), $H$ HGF + HEMA, $M$ HGF+ S. mutans ATCC25175, HM $\mathrm{HGF}+\mathrm{HEMA}+S$. mutans ATCC 25175
A

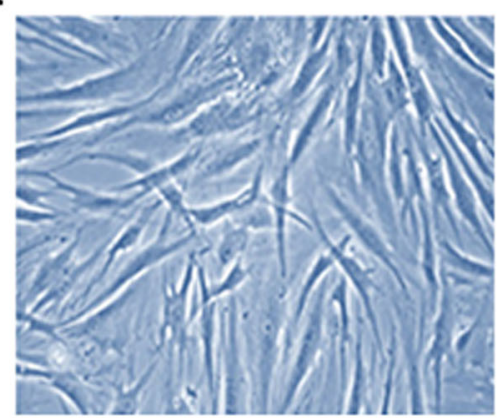

\section{c}

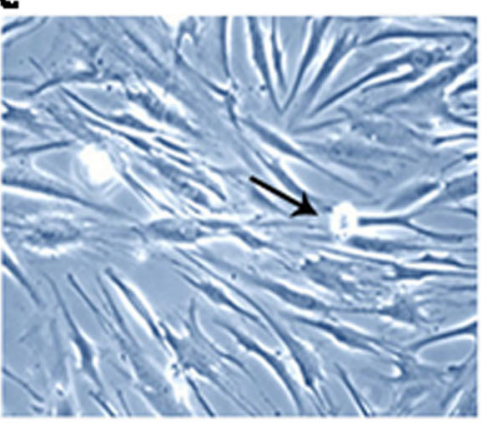

H

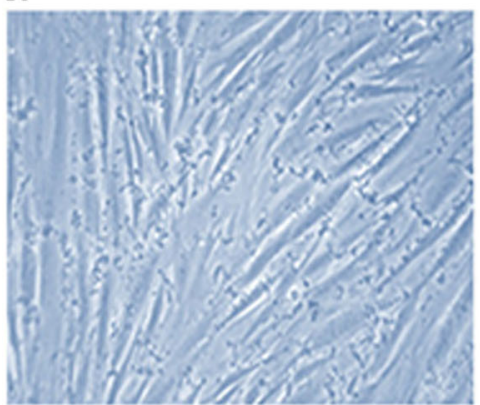

M

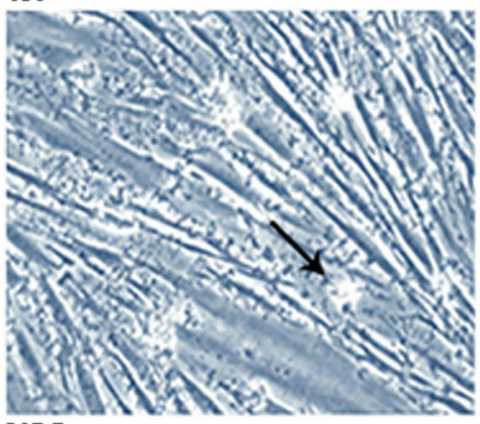

B

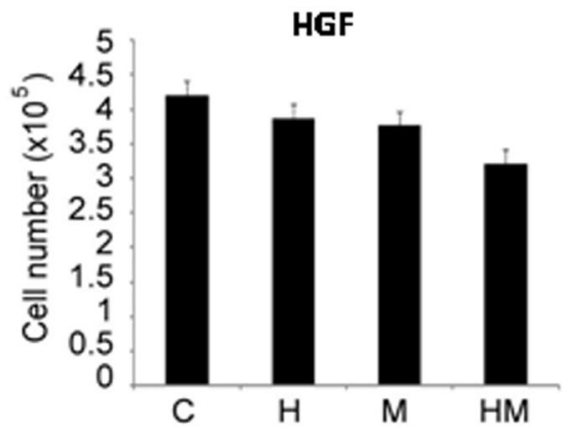

C

\section{S.Mutans ATCC25175}

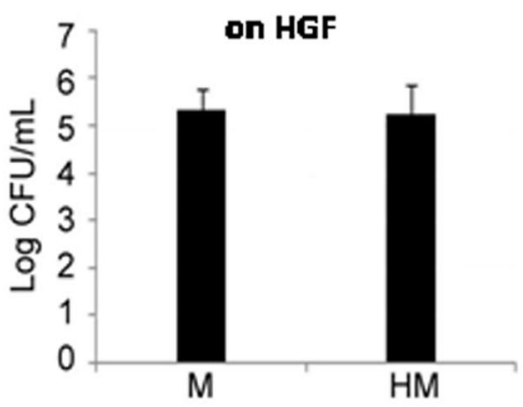

D

\% LDH leakage vs Ctr

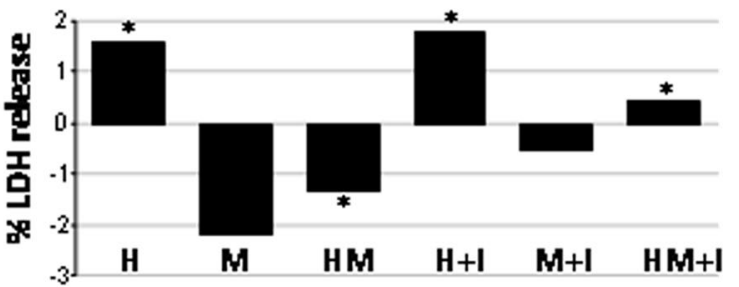

HM

pathogen and/or toxic substances, but it is fundamental to evaluate the interactions between biomaterials/bacteria/host.

Moreover, since the interaction between microbial and oral tissue is almost unexplored, in this study, we have tested the effects of HEMA monomer on HGF/S. mutans co-cultured cells.

Human gingival fibroblasts are connective cells which can either mediate the adhesion to bone structure by producing procollagen I protein or interact with microbial cells. Thus, with the aim to investigate the human gingival fibroblasts' response both to HEMA and bacteria in terms of adhesion and viability, in our lab, an $\mathrm{HGF} / S$. mutans co-culture model has been set up. In particular, while in the presence of HEMA viability is not significantly modified in each experimental condition, adhesion, shown by procollagen I expression, is significantly reduced in the presence of HEMA plus or minus S. mutans, not affected by S. mutans alone. Even bacteria viability, assayed by CFU counts, does not show any 
A

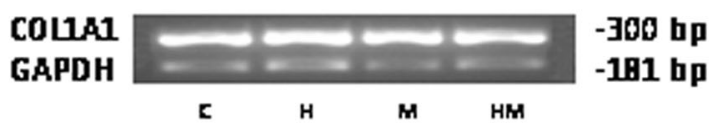

C

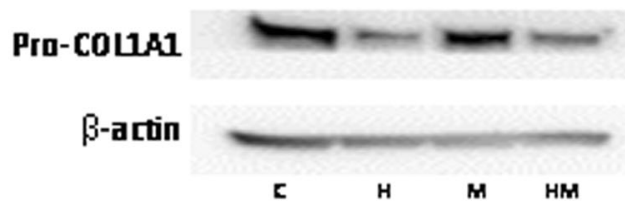

B

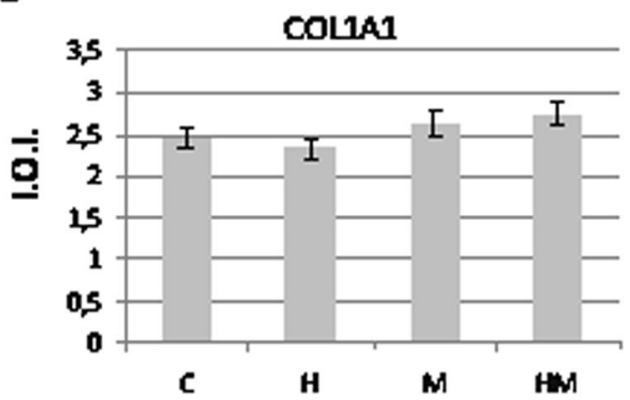

D

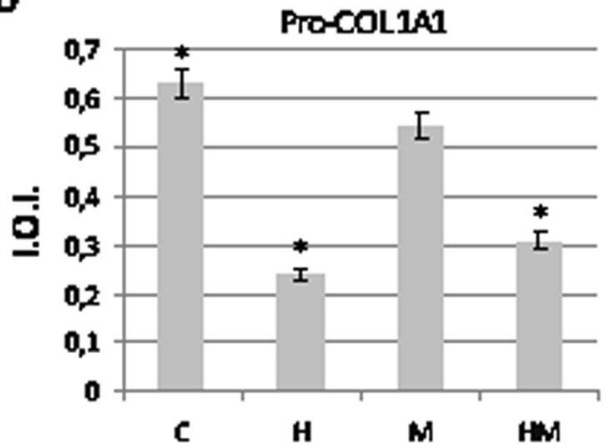

Fig. 2 a Representative image of the expression of CoL1A1 normalized with the expression of the internal control GAPDH. b Densitometric analysis $( \pm \mathrm{SD})$ of CoL1A1 gene expression. c Western blot analysis of procollagen I expression in HGF exposed for $24 \mathrm{~h}$ to $3 \mathrm{mM}$ HEMA cocultured or not in the presence of $S$. mutans ATCC 25175. Total protein

modification upon HEMA treatment. Since collagen synthesis inhibition has been elsewhere reported to be regulated by NF$\mathrm{kB}$ activation [30], here we report increased $\mathrm{p}-\mathrm{IkB} \alpha / \mathrm{IkB} \alpha$
$-210 \mathrm{kDa}$

$-43 \mathrm{kDa}$
Fig. 3 a Western blot analysis of $\mathrm{NF}-\mathrm{kB}, \mathrm{IkB} \alpha$ and $\mathrm{p}-\mathrm{IkB} \alpha$ expression in $\mathrm{HGF}$ exposed for $24 \mathrm{~h}$ to 3 mM HEMA co-cultured or not in the presence of $S$. mutans. When required, the NF-kB/Ikb pharmacological inhibitor SN50 has been added to the culture 45 min before $S$. mutans and HEMA treatment. Total protein $(60 \mu \mathrm{g})$ has been loaded for each lane and the membrane probed with $\beta$-actin antibody to verify loading evenness. The blot is the most representative out of three independent experiments performed in duplicate. b Densitometric analysis $( \pm \mathrm{SD})$ of $\mathrm{p}-\mathrm{IkB} \alpha /$ $\mathrm{IkB} \alpha$ ratio. For legend, see Fig. 1; $H, M, H M$ versus $C \mathrm{p}-\mathrm{IkB} \alpha$ : $p<0.05$
A

$(60 \mu \mathrm{g})$ has been loaded for each lane and the membrane probed with $\beta$ actin antibody to verify loading evenness. The blot is the most representative out of three independent experiments performed in duplicate. d Densitometric analysis $( \pm \mathrm{SD})$ of Procollagen I protein expression. For legend, see Fig. $1 ; H, H M$ versus C pro-collagen I: $p<0.05$

ratio in parallel to reduced collagen biosynthesis, which justifies reduced cell adhesion, in response to HEMA, while when HGFs are incubated with S. mutans or HEMA and

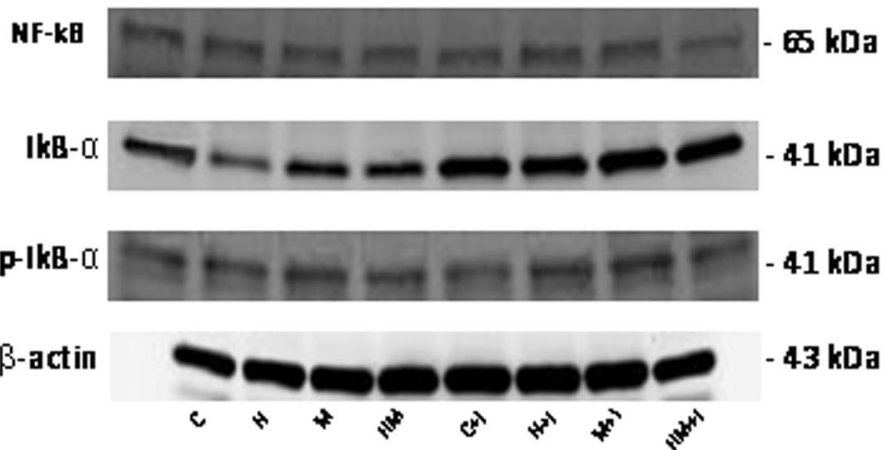

B

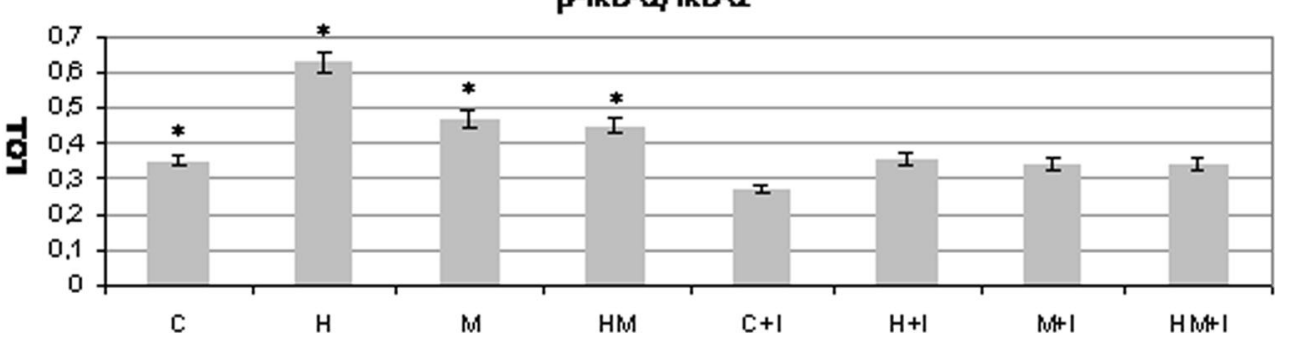

$p-l k B-\alpha / / k B-\alpha$ 
A
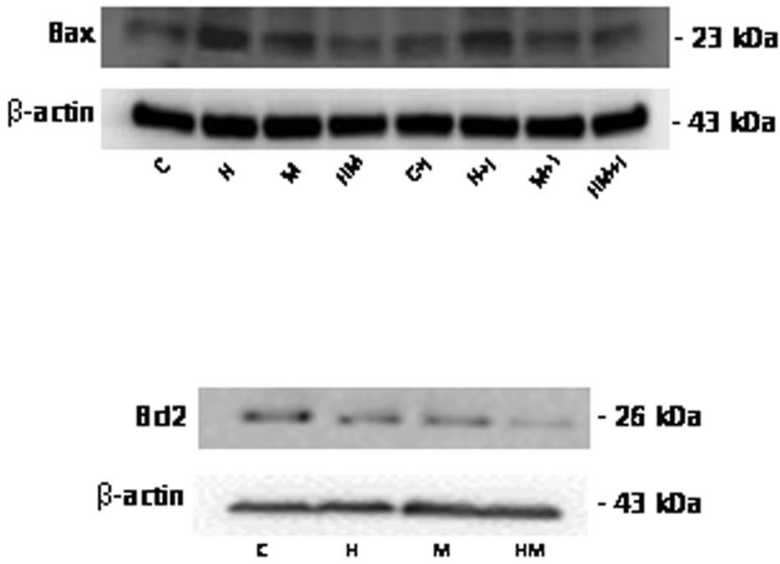

B

Bax

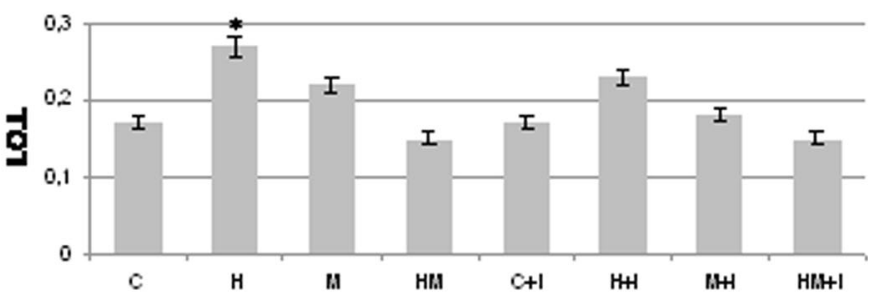

Bd2

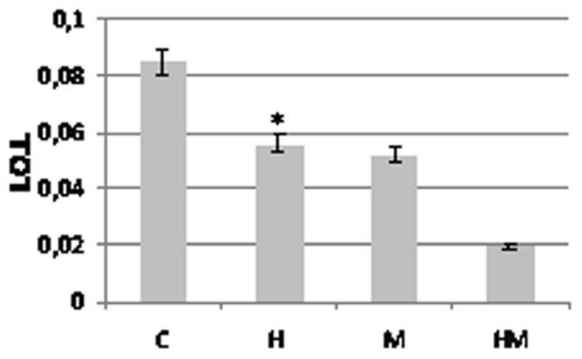

membrane probed with $\beta$-actin antibody to verify loading evenness. The blot is the most representative out of three independent experiments performed in duplicate. b Densitometric analysis $( \pm \mathrm{SD})$ of Bax and Bcl-2 expression. For legend, see Fig. 1; $H, M, H M$ versus $C$ Bax: $p<0.05 ; H, M, H M$ versus $C$ Bcl-2: $p<0.05$

key role for NF-kB in the anti-proliferative response of human gingival fibroblasts. Moreover, upon inhibitor treatment, no modification is observed in Bax expression suggesting that cells do not undergo apoptosis.

Even though to improve this co-culture model in order to resemble the oral cavity environment, saliva should be added, as already reported by our group in the presence of Streptococcus mitis strains $[48,49]$, here it has not been included since it does not significantly modify the $S$. mutans adhesion capability in the presence of biomaterials, as elsewhere already described [50].

The evidence that HEMA reduces cell adhesion and viability of HGF cells and that this response is modulated by S. mutans presence and driven by the NF-kB signalling pathway suggests that in the oral cavity, the eukaryotic/prokaryotic cells' interaction, maintaining the balance within the environment, allows HEMA to exert its adhesive and bonding function and that the use of a co-culture system, which simulates oral cavity organization, improves the knowledge concerning biocompatibility of this dental material.

Acknowledgments This work has been supported by FIRB Accordi di Programma 2010 Prof A. Cataldi: PROCESSI DEGENERATIVI DEI TESSUTI MINERALIZZATI DEL CAVO ORALE, IMPIEGO DI BIOMATERIALI E CONTROLLO DELLE INTERAZIONI CON MICROORGANISMI DELL'AMBIENTE. Prot: RBAP1095CR and MIUR PRIN 2009 Prof. A.Cataldi : Ruolo delle Protein Chinasi C (PKC) nei processi di interazione/integrazione tra biomateriale dentale/tessuto ospite/flora microbica della cavità orale. Prot. 2009FXT3WL_002. 
Conflict of interest The authors declare that they have no conflict of interest.

Open Access This article is distributed under the terms of the Creative Commons Attribution License which permits any use, distribution, and reproduction in any medium, provided the original author(s) and the source are credited.

\section{References}

1. Bakopoulou A, Papadopoulos T, Garefis P (2009) Molecular toxicology of substances released from resin-based dental restorative materials. Int J Mol Sci 3861-3899

2. Durner J, Wellner P, Hickel R, Reichl FX (2012) Synergistic interaction caused to human gingival fibroblasts from dental monomers. Dent Mater 28:818-823

3. Nakabayashi N, Takarada K (1992) Effect of HEMA on bonding to dentin. Dent Mater 8:125-130

4. Schweikl H, Spagnuolo G, Schmalz G (2006) Genetic and cellular toxicology of dental resin monomers. J Dent Res 85:870-877

5. Gawkrodger DJ (2005) Investigation of reactions to dental materials. Br J Dermatol 153:479-485

6. Krifka S, Seidenader C, Hiller KA, Scmalz G, Schweikl H (2012) Oxidative stress and cytotoxicity generated by dental composites in human pulp cells. Clin Oral Invest 16:215-224

7. Goldberg M (2008) In vitro and in vivo studies on the toxicity of dental resin components: a review. Clin Oral Invest 12:1-8

8. Samuelsen JT, Holme JA, Becher R, Karlsson S, Morisbak E, Dahl JE (2008) HEMA reduces cell proliferation and induces apoptosis in vitro. Dent Mater 24:134-140

9. Trubiani O, Cataldi A, De Angelis F, D'Arcangelo C, Caputi S (2012) Overexpression of interleukin-6 and -8, cell growth inhibition and morphological changes in 2-hydroxyethyl methacrylate-treated human dental pulp mesenchymal stem cells. Int Endod J 45:19-25

10. Cataldi A, Zara S, Rapino M, Patruno A, di Giacomo V (2013) Human gingival fibroblasts stress response to HEMA: a role for protein kinase $\mathrm{C} \alpha$. J Biomed Mater Res A 101:378-384

11. Spagnuolo G, D’Antò V, Cosentino C, Schmalz G, Schweikl H, Rengo S (2006) Effect of N-acetyl-cysteine on ROS production and cell death caused by HEMA in human primary gingival fibroblasts. Biomaterials 27:1803-1809

12. Volk J, Engelmann J, Leyhausen G, Geurtsen W (2006) Effects of three resin monomers on the cellular glutathione concentration of cultured human gingival fibroblasts. Dent Mater 22:499-505

13. Trubiani O, Caputi S, Di Iorio D, D'Amario M, Paludi M, Giancola R, Di Nardo Di Maio F, De Angelis F, D' Arcangelo C (2010) The cytotoxic effects of resin-based sealers on dental pulp stem cells. Int Eng J 8:646-653

14. Samuelsen JT, Kopperud HM, Holme JA, Dragland IS, Christensen T, Dahl JE (2011) Role of thiol-complex formation in 2hydroxyethyl-methacrylate-induced toxicity in vitro. J Biomater Res A 96:395-401

15. Gallorini M, Cataldi A, di Giacomo V (2013) HEMA-induced cytoxicity: oxidative stress, genotoxicity and apoptosis. Int Endod J. doi:10.1111/iej.12232

16. Kurata S, Morishita K, Kawase T, Umemoto K (2012) Cytotoxic effects of acrylic acid, methacrylic acid, their corresponding saturated carboxylic acids, HEMA, and hydroquinone on fibroblasts derived from human pulp. Dent Mater J 31:219-225

17. Socransky SS, Haffajee AD, Cugini MA, Smith C, Kent RL Jr (1998) Microbial complexes in subgingival plaque. J Clin Periodontol 25: 134-144
18. Dewhirst FE, Chen T, Izard J, Paster BJ, Tanner ACR, Yu WH, Lakshmanan A, Wade WG (2010) The human oral microbiome. J Bacteriol 192:5002-5017

19. Jenkinson HF (2011) Beyond the oral microbiome. Environ Microbiol 13:3077-3087

20. Loesche WJ (1986) Role of Streptococcus mutans in human dental decay. Microbiol Rev 50:353-380

21. Li L, Finnegan MB, Ozkan S, Kim Y, Lillehoj PB, Ho CM, Lux R, Mito R, Loewy Z, Shi W (2010) In vitro study of biofilm formation and effectiveness of antimicrobial treatment on various dental material surfaces. Mol Oral Microbiol 25:384-390

22. Nicolas GG, Lavoie MC (2011) Streptococcus mutans and oral streptococci in dental plaque. Can J Microbiol 57:1-20

23. Gross EL, Beall CJ, Kutsch SR, Firestone ND, Leys EJ, Griffen AL (2012) Beyond Streptococcus mutans: dental caries onset linked to multiple species by $16 \mathrm{~S}$ rRNA community analysis. PLoS One 7(10): e47722. doi:10.1371/journal.pone.0047722

24. Aas JA, Griffen AL, Dardis SR, Lee AM, Olsen I, Dewhirst FE, Leys EJ, Paster BJ (2008) Bacteria of dental caries in primary and permanent teeth in children and young adults. J Clin Microbiol 46:1407-1417

25. Tanner AC, Mathney JM, Kent RL, Chalmers NI, Hughes CV, Loo CY, Pradhan N, Kanasi E, Hwang J, Dahlan MA, Papadopolou E, Dewhirst FE (2011) Cultivable anaerobic microbiota of severe early childhood caries. J Clin Microbiol 49:1464-1474

26. Engels-Deutsch M, Rizk S, Haïkel Y (2011) Streptococcus mutans antigen I/II binds to $\alpha 5 \beta 1$ integrins via its A-domain and increases $\beta 1$ integrins expression on periodontal ligament fibroblast cells. Arch Oral Biol 56:22-28

27. Zhu T, Lim BS, Park HC, Son KM, Yang HC (2012) Effects of the iron-chelating agent deferoxamine on triethylene glycol dimethacrylate, 2-hydroxylethyl methacrylate, Hydrogen peroxideinduced cytotoxicity. J Biomed Mater Res B Appl Biomater 100: 197-205

28. Di Nisio C, Zara S, Cataldi A, di Giacomo V (2013) 2-Hydroxyethyl methacrylate inflammatory effects in human gingival fibroblasts. Int Endod J 46:466-476

29. Gilmore TD (2006) Introduction to NF-kB: players, pathways, perspectives. Oncogene 25:6680-6684

30. Karna E, Nazaruk J, Szoka L, Palka JA (2011) Scutellarin-dependent inhibition of collagen biosynthesis in cultured fibroblasts. Nat Prod Res 25:1789-1795

31. Chen F, Castranova V, Shi X (2001) New insights into the role of Nf$\mathrm{kB}$ in cell growth regulation. Am J Pathol 159:387-397

32. Cataldi A, Rapino M, Centurione L, Sabatini N, Grifone G, Garaci F, Rana RA (2003) Nf-kB activation plays an anti-apoptotic role in human leukemic K562 cells exposed to ionizing radiation. J Cell Biochem 89:956-963

33. Hayden MS, Ghosh S (2004) Signaling to Nf-kB. Genes Dev 18: 2195-2224

34. Hayden MS, Ghosh S (2008) Shared principles in Nf-kB signaling. Cell 132:344-362

35. Sun SC, Levy SC (2008) New insights into Nf-kB regulation and function. Trends Immunol 29:469-478

36. Nazari M, Ghorbani A, Hekmat-Doost A, Jeddi-Tehrani M, Zand H (2011) Inactivation of Nf-kB by citrus flavanone hesperidin contributes to apoptosis and chemo-sensitizing effect in Ramos cells. Eur J Pharmacol 650:526-533

37. Dolcet X, Llobet D, Pallares J, Matias-Guiu X (2005) Nf-kB in development and progression of human cancer. Virchows Arch 446:475-482

38. Spagnuolo G, Mauro C, Leonardi A, Santillo M, Paternò R, Schweikl H, Avvedimento EV, Rengo S (2004) NF-kappa B protection against apoptosis induced by HEMA. J Dent Res 83:837-842

39. Paranjpe A, Cacalano NA, Hume WR, Jewett A (2007) Nacetylcysteine protects dental pulp stromal cells from HEMA- 
induced apoptosis by inducing differentiation of the cells. Free Radic Biol Med 43:1394-1408

40. Paranjpe A, Cacalano NA, Hume WR, Jewett A (2009) Nacetylcysteine mediates protection from HEMA-induced apoptosis via NF-kB dependent and independent pathways: potential involvement of JNK. Toxicol Sci 108:356-366

41. Zara S, Di Giulio M, D' Ercole S, Cellini L, Cataldi A (2011) Antiadhesive and pro-apoptotic effects of 2-hydroxyethyl methacrylate on human gingival fibroblasts co-cultured with Streptococcus mitis strains. Int Endod J 44:1145-1154

42. Di Giulio M, D' Ercole S, Zara S, Cataldi A, Cellini L (2012) Streptococcus Mitis/Human gingival fibroblasts co-culture: the best natural association in answer to HEMA release. APMIS 120:139146

43. Falconi M, Teti G, Zago M, Pelotti S, Breschi L, Mazzotti G (2007) Effects of HEMA on type I collagen protein in human gingival fibroblasts. Cell Biol Toxicol 23:313-322

44. Lin YZ, Yao SY, Veach RA, Torgerson TR, Hawiger J (1995) Inhibition of nuclear translocation of transcription factor NF-kB by a synthetic peptide containing a cell membrane -permeable motif and nuclear localization sequence. J Biol Chem 270: $14255-14258$
45. Mincione G, Piccirelli A, Lazzereschi D, Salomon DS, Colletta G (1998) Heregulin-dependent autocrine loop regulates growth of K-ras but not erbB-2 transformed rat thyroid epithelial cells. J Cell Physiol 176:383-391

46. Palmqvist $P$, Lundberg $P$, Lundgren I, Hänström L, Lerner UH (2008) IL- $1 \beta$ and TNF- $\alpha$ regulate IL-6-type cytokines in gingival fibroblasts. J Dent Res 87:558-563

47. Johansson A, Bergenholtz A, Holm SE (1996) The interference of gingival cell cultures with growth of selected bacteria. APMIS 104: $367-373$

48. di Giacomo V, Pacella S, Rapino M, Di Giulio M, Zara S, Pasquantonio G, Cellini L, Cataldi A (2013) pPKC $\alpha$ regulates through integrin $\beta 1$ human gingival fibroblasts /Streptococcus mitis adhesion in response to HEMA. Int Endod J 46:1164-1172

49. Di Giulio M, di Giacomo V, Di Campli E, Di Bartolomeo S, Zara S, Pasquantonio G, Cataldi A, Cellini L (2013) Saliva improves Streptococcus mitis protective effect on human gingival fibroblasts in presence of 2-hydroxyethyl-methacrylate. J Mater Sci Mater Med 24:1977-1983

50. Rosenbloom RG, Tinanoff N (1991) Salivary Streptococcus mutans levels in patients before, during, and after orthodontic treatment. Am Orthod Dentofac 100:35-37 